\title{
PANDANGAN ANGGOTA ORMAS ISLAM DI WILAYAH MALUKU TERHADAP IMUNISASI/VAKSINASI MENINGITIS SERTA KAJIANNYA SECARA BIOLOGI
}

\author{
Nirmala F. $\mathrm{F}^{1}$, Titin Hartina $\mathrm{L}^{2}$ \\ 1,2 Jurusan Pendidikan Biologi, IAIN Ambon \\ E-mail: nirmala_fitria@yahoo.co.id
}

\begin{abstract}
Abstrak: Berdasarkan hasil wawancara dengan informan dari lima ormas Islam di Maluku didapatkan bahwa 36\% dari mereka menyatakan bahwa vaksinasi meningitis bagi calon jemaah haji/umroh merupakan langkah yang sangat tepat dan patut didukung oleh semua pihak, karena dapat memberikan dampak yang sangat baik bagi kesehatan jemaah saat beribadah di tanah suci dan mencegah penularan penyakit tersebut kepada keluarga saat mereka pulang ke tanah air dan $64 \%$ sisanya tidak memberikan tanggapan. Tidak ada larangan khusus untuk hal ini akan tetapi disesuaikan dengan pemahaman masing-masing anggota. Terdapat enam masalah yang kemudian dikaji secara biologi yakni: 1) Vaksin bukanlah obat tetapi merupakan sediaan biologis yang diproduksi dari organisme hidup (virus/bakteri) yang dapat merangsang imunitas, 2) vaksin diberikan untuk menghasilkan antibodi yang berguna untuk melumpuhkan penyakit saat masuk kedalam tubuh, 3) perlindungan yang diberikan vaksin sekitar 80-90\% akan tetapi lebih baik daripada tidak diberikan samasekali, 4) bahan pengawet pada vaksin berguna untuk menghindari kontaminasi bakteri/fungi (ex. Thimerosal), 5) material turunan hewan dalam vaksin (serum, tripsin, asam amino, albumin, gelatin dll) di dapatkan dari sapi, babi dan kera, (6) Semua vaksin mengandung komponen aktif (antigen) yang berfungsi untuk membentuk respon imun.
\end{abstract}

Kata Kunci: Imunisasi, Vaksinasi Meningitis, Kajian Secara Biologi
THE VIEWS OF A MEMBER OF ISLAMIC MASS ORGANIZATIONS IN THE REGION OF MALUKU AGAINST THEIR CHILDREN IMMUNIZATIONS/VACCINATION MENINGITIS AS WELL AS RESULT IN CONCRETE BIOLOGICAL TERMS

\begin{abstract}
: the results of interviews with the informants from five islamic mass organizations in Maluku causing got that $36 \%$ from they have stated that vaccination meningitis for prospective three days during the days congregation in the outer courts/umroh was a good step in who is very exact and must be supported by all parties, because it can be an impact that very bad for the health congregation in the outer courts
\end{abstract}

BIOLOGI SEL (VOL 6 NO 1 EDISI JAN-JUN 2017 ISSN 2252-858X/E-ISSN 2541-1225) PAGE 69 
served on the the holy land and preventing the contagion of the disease upon the house of recovery of form as they home to the land water and $64 \%$ the rest did not to give any response. That no decree in particular regard to the it is going to but adapted to the understanding masing-masing a member of. There were six a problem to the point where it under review in concrete biological terms of bond issuance will be: 1 ) vaccine is not a sedative but a biological preparation produced from living organisms (virus/bacteria) that stimulate immunity, 2 ) vaccine given to produces antibodies are useful to crippling disease when he came into a state of body, 3 ) protection afforded vaccine about 80-90\% but given it is better than nothing at all, 4 ) preservative in vaccines useful to avoid contaminating bacteria/fungi (ex. thimerosal), 5 ) material derived animals in vaccine (serum, trypsin, an amino acid, albumin, gelatin, etc) there from cows, pigs and monkeys, 6 ) all vaccines containing active component (antigens) that serves to form an immune response.

\section{Keywords: Immunization, Vaccination Meningitis, The Study In Biology}

Istilah imunisasi dan vaksinasi sudah akrab di telinga masyarakat dan merupakan salah satu bagian dari program wajib yang digalakkan oleh Pemerintah. Imunisasi merupakan istilah yang lebih umum untuk proses kekebalan tubuh, sedangkan vaksinasi adalah proses imunisasi yang khusus menggunakan vaksin saja. Secara teori vaksinasi adalah pemberian vaksin (antigen dari virus/bakteri) yang dapat merangsang imunitas (antibodi) dari sistem imun di dalam tubuh, dalam kata lain seperti memberi infeksi ringan pada tubuh (Rahmatiah, 2015).

Imunisasi/vaksinasi dalam pelaksanaanya banyak terjadi pro dan kontra. Isu-isu yang muncul terhadap vaksinasi antara lain vaksin haram disebabkan karena menggunakan media ginjal kera, babi, aborsi bayi, darah orang yang tertular penyakit infeksi yang notabene pengguna alkohol, obat bius, dan lain-lain. Selain itu mereka menganggap bahwa vaksinasi membahayakan karena mengandung mercuri, thimerosal, alumunium, benzetonium klorida, dan zat-zat berbahaya lainnya yang akan memicu autism, cacat otak dan lain-lain. Sehingga mereka beranggapan bahwa vaksinasi lebih banyak bahayanya daripada manfaatnya (Bahraen. R, 2011).

Berdasarkan hasil survey awal kepada beberapa anggota ormas Islam yang ada di Maluku, peneliti mendapatkan fenomena bahwa tidak semua anggota ormas Islam mengetahui secara pasti mengenai sebab dilarangnya imunisasi dalam organisasi mereka. Mereka cenderung menganggap pelarangan disebabkan karena isu-isu yang berkembang di masyarakat yang telah disebutkan di atas. Bahkan mereka secara pribadi belum paham mengenai konsep vaksinasi dan cara pembuatannya.

Kondisi ini kemudian berkembang dimana kemudian isu larangan vaksinasi oleh beberapa ormas Islam dihadapkan dengan kewajiban vaksinasi meningitis kepada para 
calon jemaah haji. Menurut peraturan Permenkes no 58 Tahun 2013 tentang pemberian sertifikat vaksinasi internasional menyatakan bahwa setiap orang yang akan melakukan perjalanan internasional dari dan ke negara terjangkit dan/atau endemis penyakit menular tertentu dan/atau atas permintaan negara tujuan wajib diberikan vaksinasi tertentu sesuai ketentuan peraturan perundang-undangan. Vaksin meningitis wajib dilaksanakan oleh jemaah haji untuk melindungi dari penyakit meningitis (Peraturan Menteri Kesehatan, 2013).

Penyakit Meningitis adalah infeksi cairan otak disertai radang yang mengenai piameter (lapisan dalam selaput otak) dan arakhnoid serta dalam derajat yang lebih ringan mengenai jaringan otak dan medula spinalis yang superfisial (Israr, 2008). Bakteri Neisseria meningitidis (Meningokokus) jarang ditemukan di Indonesia. Sehingga banyak orang Indonesia yang tidak memiliki kekebalan terhadap bakteri tersebut. Vaksinasi sangat dianjurkan bagi orang Indonesia yang bepergian ke wilayah berisiko tinggi. Daerah yang berisiko tinggi atau daerah asal bakteri ini adalah Arab Saudi dan sebagian Negara-negara di Afrika (Harsono, 2003).

Berdasarkan latar belakang tersebut maka peneliti ingin menggali informasi yang lebih mendalam mengenai pendapat beberapa ormas Islam yang ada di Maluku baik dari Pengurus organisasi maupun dari para anggota organisasi mengenai vaksinasi meningitis untuk jemaah haji dan umroh. Data-data yang sudah digali kemudian akan diulas atau dikaji berdasarkan ilmu biologi (Sains) yang sesuai dari jurnal maupun pustaka yang diterbitkan oleh para ahli. Informasi yang diharapkan dapat meluruskan kondisi pro maupun kontra yang berkembang di masyarakat.

\section{METODE PENELITIAN}

Penelitian ini adalah penelitian diskriptif kualitatif yang menggambarkan kondisi lapangan mengenai pandangan anggota ormas Islam di Maluku terhadap program vaksinasi/imunisasi Meningitis yang dicanangkan oleh pemerintah. Untuk kemudian data yang didapatkan dikaji secara biologi (sains) melalui pustaka dan jurnal-jurnal dari pihak yang berkompeten dibidang imunisasi/vaksinasi. Yang menjadi subjek penelitian ini adalah perwakilan dari beberapa anggota ormas Islam di Maluku yaitu dari Nahdatul Ulama, Muhammadiyah, LDII, Jamaah Tabligh, Salafi, meliputi 10 orang anggota dari ormas Islam tersebut sebagai perwakilan masyarakat Islam.

Objek penelitian ini adalah pandangan anggota ormas Islam di Maluku terhadap vaksinasi/imunisasi Meningitis beserta kajiannya secara teori biologi (Sains). Sumber data primer yang digunakan hanya dari hasil wawancara langsung dengan informan.

Sedangkan, sumber data sekunder yang digunakan adalah literature dan jurnal yang berkaitan dengan penelitian baik dari dalam maupun luar negeri. Data sekunder tidak diambil dari blog bebas seperti Wikipedia, blogspot, ataupun wordpress yang tidak diketahui secara jelas orisinalitasnya, data hanya di unduh dari web resmi. Pengumpulan 
data primer dilakukan dengan menggunakan metode tanya jawab/wawancara secara mendalam. Data yang di dapat disajikan secara deskriptif untuk kemudian dikembangkan sesuai dengan informasi yang di dapat dari hasil wawancara.

\section{HASIL DAN PEMBAHASAN}

Berdasarkan hasil wawancara oleh informan (responden) didapatkan bahwa 66\% dari anggota ormas Islam di Maluku memahami apa yang dimaksud dengan vaksinasi/imunisasi. Sedangkan 34\% sisanya kurang paham terhadap hal tersebut. Dan tidak didapatkan informan yang tidak paham dengan apa yang dimaksud dengan vaksinasi/imunisasi. Informan dapat dikategorikan paham jika informan tersebut mampu menjelaskan bahwa vaksin merupakan bibit penyakit yang dilemahkan atau dinonaktifkan dan bukanlah suatu obat yang digunakan untuk meningkatkan kekebalan tubuh. Sedangkan untuk informasi tehadap vaksinasi meningitis terdapat $64 \%$ dari anggota ormas Islam telah mengetahui tentang vaksinasi meningitis, 30\% kurang mengetahui dan 6\% tidak mengetahui hal tersebut.

Berbagai macam tanggapan diberikan oleh para informan mengenai vaksin dan program wajib vaksinasi meningitis yang digalakkan oleh pemerintah. Terdapat $36 \%$ dari mereka menyatakan bahwa vaksinasi meningitis bagi calon jemaah haji/umroh merupakan langkah yang tepat dan patut didukung oleh semua pihak, karena dapat memberikan dampak yang sangat baik bagi kesehatan jemaah saat beribadah di tanah suci dan mencegah penularan penyakit tersebut kepada keluarga saat jemaah haji/umroh pulang ke tanah air. Sedangkan 64\% sisanya tidak memberikan tanggapan terhadap vaksinasi meningitis. Dalam proses wawancara juga didapatkan pernyataan bahwa tidak ada larangan khusus dari Organisasi mereka tentang vaksinasi/imunisasi akan tetapi disesuaikan dengan pemahaman masing-masing anggota Ormas Islam tersebut selama tidak membawa kemudhorotan (kejelekan) dan melanggar hak asasi manusia. Dengan syarat pemerintah harus melakukan pengawasan terhadap peredaran dan pembuatan vaksin tersebut sehingga tidak menimbulkan keragu-raguan. Seperti dengan cara pengawasan bahan baku dan penelitian-penelitian mengenai kehalalan vaksin. Imunisasi pada dasarnya diperbolehkan (mubah) sebagai bentuk ikhtiar untuk mewujudkan kekebalan tubuh (imunitas) dan mencegah terjadinya suatu penyakit tertentu (MUI, 2016).

Beberapa permasalahan didapatkan selama proses wawancara dengan beberapa informan dari ke lima Ormas Islam di Maluku. Permasalahan ini cukup penting untuk diulas karena sebagian besar memberikan efek negatif dalam program vaksinasi meningitis. Permasalahan yang ditemukan adalah sebagai berikut:

1. Menganggap vaksin adalah obat

2. Menganggap vaksin dapat menghilangkan penyakit (di imunisasi akan tetapi tetap sakit) 
3. Tidak terlihat manfaatnya secara langsung

4. Terdapat bahan pengawet (mengandung racun)

5. Mengandung unsur babi/kera, mengandung lemak babi, sum-sum babi

6. Tidak tercantum bahan pembuatan

Permasalahan-permasalahan yang tersebut diatas merupakan salah satu wujud cerminan kurang pahamanya masyarakat awam mengenai konsep dasar dari imunisasi/vaksinasi. Kekurang pahaman ini kemungkinan disebabkan karena kurangnya informasi mengenai imunisasi/vaksinasi. Informasi yang dimaksud bisa berupa referensi atau penyuluhan dari dinas yang bersangkutan seperti Dinas Kesehatan, MUI dan BPPOM. Untuk menjawab permasalahan tersebut maka berikut akan dikaji secara sains (biologi) berdasarkan referensi dan jurnal-jurnal penelitian yang didapatkan.

\section{Vaksin Bukan Obat}

Vaksin bukanlah salah satu jenis obat yang dapat menyembuhkan suatu penyakit. Vaksin secara umum adalah sediaan biologis yang diproduksi dari organisme hidup yang dapat meningkatkan kekebalan (imunitas) akibat penyakit (Pharma, 2012). Sedangkan obat adalah suatu zat yang digunakan untuk diagnose, pengobatan, melunakkan, penyembuhan dan pencegahan penyakit pada manusia atau hewan. Obat umumnya berasal dari zat aktif yang berbahan alami ataupun sintesis (Sulistyowati, 2010).

Vaksin mengandung virus hidup, virus mati, protein virus yang dimurnikan, bakteri toksik yang dinonaktifkan, ataupun polisakarida dari bakteri. Sehingga vaksinasi dapat diartikan sebagai pemberian vaksin kepada balita/dewasa untuk meningkatkan kekebalan terhadap suatu penyakit.Vaksinasi merupakan salah satu contoh imunisasi aktif. Imunisasi aktif adalah upaya merangsang (stimulasi) system imun untuk memproduksi antigen spesifikhumoral (antibody) dan imunitas seluler (Offit and Jew, 2003).

Salah satu cara untuk memperoleh imunitas aktif adalah dengan bertahan dari infeksi penyakit. Orang yang berhasil sembuh dari infeksi suatu penyakit maka mereka akan memiliki imunitas yang panjang terhadap penyakit tersebut. Kemampuan melindungi dalam beberapa tahun setelah infeksi dikenal dengan immunologic memory. Selama paparan system imun terhadap antigen, sel-sel tertentu (memorisel B) akan terus beredar didalam darah (dan juga berada di sum-sum tulang) dalam beberapa tahun. Pada saat kembali terpapar antigen, sel memori ini akan mulai mereplikasi dan memproduksi antibody dengan sangat cepat untuk kembali membangun perlindungan.

Beberapa vaksin juga memproduksi memori immunologi yang sama yang diperoleh dari penyakit alamiah. Ada dua tipe dasar dari vaksin, yaitu mikroorganisme hidup yang dilemahkan (live attuated) dan mikroorganisme yang dinonaktifkan (inactivated). Perbedaan karakteristik vaksin hidup dan inaktif terletak pada bagaimana cara vaksin didapatkan. Vaksin hidup diproduksi dengan memodifikasi virus penyebab penyakit atau bakteri di laboratorium. Vaksin ini mempertahankan kemampuannya untuk 
bereplikasi (tumbuh) dan memproduksi imunitas, namun biasanya tidak menyebabkan penyakit. Bakteri atau virus liar ini dilemahkan di labiratorium biasanya dengan kultur berulang. Contohnya virus campak yang digunakan sebagai vaksin sekarang telah diisolasi dari anak yang menderita penyakit campak di tahun 1945. Selama 10 tahun dengan mengunakan beberapa seri bagian media kultur jaringan (tissue) diperlukan untuk merubah virus liar mejadi vaksin virus yang dilemahkan.

Untuk memproduksi respon imun, vaksin hidup harus digandakan (ditumbuhkan) pad orang yang divaksin. Dosis bakteri atau virus yang diberikan relatif lebih kecil, yang kemudian akan bereplikasi di dalam tubuh dan menciptakan organisme yang cukup untuk merangsang respon imun. Beberapa hal yang dapat merusak organisme hidup dalam vial (panas dan cahaya) atau ikut campur dalam replikasi organisme di dalam tubuh (sirkulasi antibody) dapat menyebabkan vaksin menjadi tidak efektif. Meskipun vaksin hidup bereplikasi, mereka biasanya tidak menyebabkan penyakit seperti yang mungkin terjadi pada bentuk liar dari organisme tersebut. Apabila vaksin hidup ini menyebabkan penyakit maka biasanya akan lebih ringan daripada penyakit alamiah dan biasanya disebut sebagai reaksi merugikan.

\section{Menganggap Vaksin dapat Menghilangkan Penyakit}

Vaksin memiliki cara kerja yang berbeda dengan obat yang dapat menyembuhkan suatu penyakit. Vaksin tidak dapat menyembuhkan suatu penyakit yang menyerang tubuh penderita. Vaksin diberikan kedalam tubuh agar tubuh dapat menghasilkan antibody yang dapat membantu melumpuhkan penyakit pada saat masuk kedalam tubuh. Dengan kata lain vaksin membantu tubuh meningkatkan imunitas atau daya tahan tubuh, sehingga sistem imun dapat bekerja lebih cepat untuk membunuh bakteri atau virus yang masuk ke dalam tubuh.

Imunitas adalah kemampuan dari manusia untuk mentolerir kehadiran zat asing yang ada dalam tubuh (self) dan untuk mengeliminasi zat asing dari luar tubuh (nonself). Kemampuan ini berguna untuk melindungi dari infeksi penyakit, dimana beberapa mikroba diindikasikan sebagai zat asing dari luar tubuh oleh system imun. Imunitas terhadap mikroba biasanya diindikasikan dengan munculnya antibody pada organisme yang terikat erat. Ada dua mekanisme dasar dalam memperoleh immunitas yaitu aktif dan pasif.

Imunitas aktif adalah perlindungan yang didapatkan dari sistem imun orang itu sendiri. Tipe imunitas ini biasanya berlangsung selama bertahun-tahun bahkan seumur hidup. Sedangkan imunisasi pasif adalah perlindungan oleh produk yang diproduksi dari manusia atau hewan dan dipindahkan ke manusia yang lain, biasanya melalui suntikan. Imunitas pasif memberikan perlindungan yang efektif. Akan tetapi perlindungan ini berkurang (hilang) seiring bertambahnya waktu, biasanya dalam beberapa minggu atau bulan. 
Sistem imun adalah sistem kompleks dari sel interaktif yang memiliki tujuan utama untuk mengidentifikasi zat asing dari luar tubuh (non self) zat yang disebut antigen. Antigen dapat berupa materi hidup (seperti bakteri dan virus) atau materi hidup yang dilemahkan. Sistem imun dibentuk untuk melawan antigen. Perlawanan ini yang dikenal dengan respon imun dan biasanya melibatkan produksi dari molekul protein limfosit B, yang disebut antibody (immunoglobulin) dan sel spesifik termasuk limfosit $T$ (juga dikenal dengan sel perantara imunitas) yang bertujuan memfasilitasi menyisihkan subtansi zat asing dari luar tubuh.

Respon imun yang paling efektif umumnya dihasilkan dari respon terhadap antigen yang hidup. Namun antigen tidak perlu harus hidup, seperti menginfeksi dengan menggunakan virus atau bakteri untuk menghasilkan respon imun. Beberapa protein seperti antigen permukaan hepatitis B, lebih mudah dikenali oleh sistem imun. Beberapa protein seperti antigen permukaan hepatitis B, lebih mudah dikenali oleh sistem imun.Material lain seperti polisakarida (rantai panjang dari molekul gula yang menyusun dinding beberapa bakteri) kurang efektif sebagai antigen, dan respon imun mungkin tidak menghasilkan perlindungan yang baik.

a. Imunitas Pasif

Imunitas pasif adalah pemindahan antobody yang dihasilkan dari manusia atau hewan untuk lainnya. Imunitas pasif memberikan perlindungan melawan infeksi, akan tetapi ini perlindungan sementara. Antibody akan menurun selama jangka waktu satu minggu atau bulan, dan penerima tidak akan terlindungi dalam jangka waktu lama. Salah satu bentuk imunitas pasif yang paling umum adalah yang diterima bayi dari ibunya. Antibodi tersalurkan melalui plasenta pada saat kehamilan 1-2 bulan. Sebagai hasil bayi akan memiliki antibody yang sama dengan ibunya. Antibody ini akan melindungi tubuh bayi dari beberapa penyakit dalam beberapa tahun. Perlindungan baik dalam mencegah beberapa penyakit (seperti campak, rubella tetanus) dan (polio dan pertusis).

b. Imunitas Aktif

Imunitas aktif adalah upaya merangsang (stimulasi) sistem imun untuk memproduksi antigen spesifik humoral (antibodi) dan imunitas seluler. Tidak seperti imunitas pasif yang bersifat sementara, imunitas aktif biasanya bertahan untuk beberapa tahun bahkan juga seumur hidup. Salah satu cara untuk memperoleh imunitas aktif adalah dengan bertahan dari infeksi penyakit. Orang yang berhasil sembuh dari infeksi suatu penyakit maka mereka akan memiliki imunitas yang panjang terhadap penyakit tersebut. Kemampuan melindungi dalam beberapa tahun setelah infeksi dikenal dengan immunologic memory. Selama paparan sistem imun terhadap antigen, sel-sel tertentu (memori sel B) terus beredar di dalam darah (dan juga beredar di sum-sum tulang) dalam beberapa tahun. Pada saat kembali terpapar antigen, sel memori ini akan mulai mereplikasi dan memproduksi antibodi dengan sangat cepat untuk kembali membangun perlindungan. 


\section{Tidak Terlihat Manfaatnya secara Langsung}

Sebagian besar penyakit tidak memberikan kesempatan untuk hidup diluar serangan pertama. Seperti penyakit tetanus, cacar, difteri dan meningitis yang menyebabkan jutaan orang meninggal di seluruh dunia sebelum digunakannya vaksin. Penyakit ini juga menyebabkan kerusakan permanen pada tubuh individu yang masih hidup. Serangan penyakit ini tentunya cukup membahayakan bagi seseorang yang belum memiliki kekebalan dan daya tahan tubuh yang belum terbentuk sempurna. Oleh sebab itu imunisasi/vaksinasi adalah jalan terbaik untuk mencegah terjadinya serangan penyakit tersebut.

Imunisasi/vaksinasi juga dapat mencegah wabah penyakit disuatu wilayah. Pada saat daya tahan tubuh seseorang tidak memiliki pertahanan tubuh spesifik untuk virus tertentu, maka kemungkinan besar orang tersebut akan terjangkit virus tersebut dan akan menularkannya kepada orang lain sehingga memunculkan wabah. Karena kemungkinan untuk membentuk daya tahan tubuh spesifik terhadap serangan virus tertentu yang berbahaya, system imunitas tubuh kalah cepat dengan serangan virus sehingga berakibat fatal. Hal inilah yang sebenarnya dapat dicegah dengan program vaksinasi/imunisasi (Rahmatiah, 2015).

Kemampuan program vaksinasi/imunisasi dalam menurunkan resiko terjangkit penyakit juga memberikan efek pada perekonomian individu ataupun masyarakat serta sistem kesehatan nasional. Perekonomian akan semakin meningkat jika didukung oleh kesehatan masyarakat yang baik (Pharma, 2012).

\section{Mengandung Bahan Pengawet}

Vaksin dalam proses produksinya juga menggunakan bahan lain. Contohnya adalah vaksin terkadang mengandung bahan pengawet untuk menghindari kontaminasi bakteri atau fungi (misalnya: Thimerosal), bahan yang membantu meningkatkan respon antigen-specific immune (misalnya: Garam Alumunium), atau bahan tambahan yang dapat menstabilkan hidup virus yang dilemahkan (misalnya: gelatin, serum albumin manusia). Selanjutnya vaksin juga mengandung sejumlah residu dari substansi yang digunakan selama proses produksi (misalnya: formaldehyde, antibiotic, protein telur, protein, protein yeast).

a. Bahan Pengawet (preservatives)

Bahan pengawet digunakan oleh beberapa vaksin untuk menghindari kontaminasi bakteri atau fungi. Kebutuhan atas bahan pengawet pada vaksin muncul akibat adanya beberapa insiden yang terjadi pada awal abad ke 20 dimana beberapa anak mengalami infeksi bakteri fatal setelah terdata mendapatkan vaksin dalam botol multidosis. Contohnya pada tahun 1916 terdapat 4 anak yang meninggal, 26 mengalami lokal abses, dan 68 mengalami infeksi sistemik yang parah setelah mendapatkan vaksin thypoid (tipus) yang terkontaminasi dengan bakteri staphylococcus aureus atas kejadian tersebut 
dan beberapa peristiwa yang sama lainnya, maka bahan pengawet diperlukan untuk vaksin yang dikemas dalam botol multidosis sejak tahun 1930.

Tiga jenis bahan pengawet yang digunakan dalam vaksin yang terlisensi di Amerika adalah: phenol, 2-phenoxyetanol, dan thimerosal. Thimerosal, bahan pengawet yang mengandung merkuri telah menjadi fokus pengawasan oleh US congress dan media pemberitaan. Setelah itu pada tahun 2001 bahan ini dihilangkan dari vaksin anak-anak. Penghilangan thimerosal dari vaksin dikuatkan dengan amandemen yang disusun oleh Food and Drug Administration (FDA). Amandemen ini muncul dari ketertarikan yang lama pada pengurangan penggunaan merkuri pada manusia, yang dikenal dengan neurotoxin dan nephretoxin.

Merkuri sendiri adalah salah satu jenis logam yang terbentuk di lingkungan secara alami. Merkuri ditemukan dalam tiga bentuk yaitu logam merkuri yang memunculkan uap merkuri, inorganik merkuri (terbentuk di lingkungan dan jaringan hewan), dan organik merkuri (terdapat dua bentuk yaitu methylmercury dan ethylmercury). Berbagai macam jenis merkuri ditemukan di udara tanah, serta sedimen air, pada ikan (terutama pada ikan yang memiliki daur hidup yang lama seperti hiu), serta banyak digunakan pada proses industri, menambal gigi, thermometer dan vaksin. Merkuri dapat menimbulkan efek bahaya pada sistem syaraf pusat, kulit dan ginjal, akan tetapi kebanyakan kasus efek toksik dari merkuri yang dilaporkan berasal dari methylmercury bukan ethylmercury (Offit and Jew, 2003).

b. Bahan Pembantu (adjuvants)

Garam alumunium adalah sayu-satunya bahan pembantu yang saat ini terlisensi di US. Garam alumunium ditemukan awalnya untuk meningkatkan responimun setelah imunisasi penyakit dipteria dan tetanus pada penelitian yang dilakukan pada tahun 1930, 1940 dan 1950. Pada awal penelitian menunjukan garam alumunium dapat menurunkan rata-rata tingkat eliminasi dari antigen di lokasi eliminasi (misalnya efek depot). Namun, penelitian selanjutnya mempertanyakan pentingnya efek depot dan menemukan bahwa garam alumunium meningkatkan penyerapan antigen oleh sel penampil antigen (misalkan sel dendritik), mengaktifkan sel penampil antigen atau menginduksi produksi sitokin dan komplemen. Pentingnya masing-masing mekanisme ini pada peningkatan respon antigen spesifik imun masih belum jelas.

Keamanan dari alumunium telah ditetapkan berdasarkan pengalaman selama 70 tahun yang lalu, dengan ratusan juta orang yang diinokulasi dengan alumunium yang terkandung di dalam vaksin. Reaksi merugikan meliputi erythema nodul subkutan, hipersensitifitas kontak, inflamasi granulomatosa jarang didapati. Alumunium adalah salah satu dari beberapa elemen yang melimpah di kerak bumi dan juga ditemukan di udara, makanan dan air. Kandungan alumunium dalam kuantitas yang besar dapat menyebabkan efek neurologik yang serius pada manusia maka ambang batas penggunaan disusun oleh ATSDR. Untuk menentukan kuantitas alumunium yang berada dibawah 
nilai ambang batas aman, mka data didapatkan dengan menggunakan tikus yang diinokulasi secara oral dengan beberapa macam kuantitas alumunium laktat. Tidak ada reaksi merugikan yang terobservasi ketika tikus diberi alumuniumtidak lebih tinggi dari $62 \mathrm{mg} / \mathrm{kg} / \mathrm{hari}$. Dengan menerapkan faktor ketidakpastian 3 (untuk ekstrapolasi ke manusia) dan 10 (untuk variabilitas manusia). Maka ATSDR menyimpulkan bahwa level bahaya paling rendah dari paparan alumunium adalah $2 \mathrm{mg} / \mathrm{kg} / \mathrm{hari}$. Proses eliminasi alumunium dari dalam tubuh adalah kurang lebih 24 jam.

c. Bahan Tambahan (Additives)

Bahan tambahan digunakan untuk menstabilkan vaksin dari kondisi merugikan seperti proses freeze drying atau pemanasan. Disamping itu, bahan tambahan ditambahkan ke dalam vaksin untuk menghindari immunogen menumpuk disatu sisi botol. Beberapa tipe penstabil yang digunakan dalam vaksin meliputi gula (misalnya sukrosa dan laktosa), asam amino (misalnya glisin, garam monosodium atau asam glutamate) dan protein (misalnya gelatin atau serum albumin manusia).

\section{Mengandung Unsur Hewan (babi/kera)}

Proses pembuatan vaksin banyak menggunakan derivate (turunan) dari hewan. Material turunan dari hewan digunakan dalam proses kultur sel, fermentasi, purifikasi dan formulasi. Material turunan hewan yang digunakan dalam proses produksi antara lain serum, tripsin, asam amino, albumin, transferin insulin, tween 80, lipoproteins dan gelatin. Bahan-bahan ini didapatkan dari beberapa hewan misalnya sapi, babi atau manusia (Schenerman et all, 2003). Selain bahan-bahan turunan tersebut juga terdapat beberapa vaksin yang dikembangkan dalam media telur ayam, seperti vaksin influenza yang dibiakkan dalam kantung alantoik embrio ayam serta vaksin cacar dan gondok diperbanyak pada kultur sel fibroblast embrio ayam.

Sejumlah sel ini awalnya didapatkan dari memanen sel dari janin yang mengalami abortus. Sel ini digunakan untuk menumbuhkan virus kemudian dibuang an tidak termasuk didalam formula vaksin. Sel ini tidak dapat membentuk manusia. Semua vaksin memerlukan penggunaan bahan inaktif pada proses produksinya. Pada produk tersebut antara lain seperti gelatin terhidrolisis atau tripsin kemungkinan berasal dari babi atau sapi. Gelatin terhidrolisis adalah campuran dari peptide dan protein yang diproduksidengan menghidrolisis persial kolagen (serat dan jaringan ikat) yang biasanya di ekstrak dari kulit, tulang, atau komponen lain dari babi atau sapi. Hidrolisis disini adalah proses pemecahan molekul kolagen kedalam rantai asam amino (polipeptida) dengan perlakuan asam atau alkalin, diikuti dengan purifikasi. Gelatin terhidrolisis ditambahkan kepada formula vaksin untuk membantu menstabilkan dan bahan aktif ditambahkan selama proses freeze-drying dan penyimpanan. Gelatin terhidrolisis juga berfungsi sebagai pelarut. 


\section{Bahan Pembuatan}

Produksi dan komponen vaksin sangat kompleks dan sulit untuk memaksimalkan keamanan. Keamanan dari komponen individu dan vakssin itu sendiri harus didemonstrasikan sebelum vaksin tersebut dilisensikan dan digunakan. Semua vaksin mengandung komponen aktif (antigen) yang berfungsi untuk membentuk respon imun. Vaksin juga mengandung komponen tambahan. Berikut adalah deskripsi dari masingmasing bahan.

a. Tipe vaksin dan antigen vaksin

Vaksin dapat diklasifikasikan menjadi vaksin hidup, inaktif atau subunit. Jenis antigen tergabtung tipe dari vaksin, bentuk mati, dilemahkan atau fragmen dari organisme penyebab penyakit. Tubuh merespon bagian dari antigen ini dengan sangat spesifik. Bahan baku yang digunakan tergantung pada proses produksi dan asal dari antigen itu sendiri.

1) Vaksin Hidup

Virus atau bakteri yang fungsional/hidup dan dapat bereplikasi pada tubuh dalam beberapa waktu akan tetapi sudah dilemahkan jadi tidak dapat menyebabkan penyakit, contohnya virus vaksin cacar, gondok dan rubella.

2) Vaksin Mati (inaktif)

Umumnya terbuat dari virus yang dinonaktifkan atau bakteri yang dibunuh, contohnya virus influenza.

3) Vaksin Sub Unit

Terdiri dari fragmen seperti protein, toksoid atau gula (polisakarida) turunan dari organisme penyebab penyakit digunakan dalam vaksin ini.

b. Bahan Tambahan Vaksin

Subtansi lain selain bahan aktif yang termasuk dalam proses produksi atau terkandung dalam produk akhir antara lain:

1) Bahan Pembantu (ajuvan)

Bahan pembantu berfungsi untuk mendorong respon imun menjadi lebih kuat terhadap antigen vaksin.

a) Garam Alumunium

Garam Alumunium telah digunakan sebagai ajuvan selama kurang lebih 70 tahun. Umumnya adalah dalam bentuk alumunium hydroxide, Alumunium phospat dan potasium alumunium sulfat (alum). Ajuvan alumunium bekerja dengan membantu menahan antigen pada lokasi injeksi lebih lama agar sistem imun terbentuk dan dengan menginduksi sel-sel sistem dan wilayah faktor inflamasi ke tempat injeksi lokal untuk meningkatkan respon imun. Kebanyakan inaktif dan subunit vaksin menggunakan garam alumunium yang memiliki rekam jejak yang aman. Secara singkatnya penggunaan garam alumunium mengurangi kebutuhan akan antigen. Beberapa penelitian menemukan bahwa alumunium yang terkandung didalam vaksin berhubungan dengan reaksi lokal dan 
terkadang jarang berhubung dengan terbentuknya nodul subcutan pada wilayah injeksi. Ini terjadi khususnya jika injeksi diberikan tidak begitu dalam. Penelitian lain menyatakan bahwa sedikit reaksi yang terjadi karena alumunium yang terkandung didalam vaksin daripada yang tanpa alumunium, dan beberapa kasus sedikit dosis vasin yang dibutuhkan. b) MF59

MF59 adalah emulsi minyak dan air. Bahan ini dibuat dengan meggunakan squalene (minyak hidrokarbon) yang umumnya terdapat pada makanan serta diproduksi dalam tubuh sebagai prekusor untuk kolesterol dan hormon steroid. MF59 secara signifikan meningkatkan respon kekebalan tubuh terhadap berbagai antigen. Bahan ini digunakan dalam beberapa vaksin influenza di luar negeri.

c) AS03 dan AS04

Tidak semua vaksin mengandung ajuvan AS03 dan AS04. AS03 terbuat dari squalene yang sama dengan MF59. Bahan ini bisanya digunakan pada vaksin influenza di Eropa. AS04 mengandung alumunium hidroksida dan molekul yang dimodifikasi dari bakteri Salmonella minnesota. Ketakutan teoritis muncul bahwa ajuvan baru mungkin ajuvan baru mungkin menyebabkan overproduksi kejadian inflamasi yang mengawali penyakit autoimun. Namun analisis besar dengan melibatkan 68.000 orang yang menerima vaksin dengan ajuvan AS04 dan beberapa orang lain yang tidak (control) menyimpulkan bahwa kedua penerima vaksin dan control memiliki tingkat gangguan autonium yang rendah.

2) Bahan Pengawet (preservative)

Bahan pengawet umumnya digunakan untuk menghilangkan mikroba kontaminan yang tidak diinginkan dalam vaksin. Mereka biasanya menggunakan vaksin untuk beberapa tahun. Sangat sedikit efek samping yang timbul dari penggunaan pengawet tersebut.

a) 2-phenoxyethanol

Bahan yang paling umum digunakan untuk pengawet dalam vaksin adalah 2phenoxyethanol. Bahan ini juga digunakan dalam kosmetik, tetes mata dan telinga pada manusia dan iritasi pada hewan dengan penggunaan dosis yang tinggi.

b) Phenol

Phenol adalah alkohol aromatik yang jarang digunakan sebagai pengawet dalam vaksin.

c) Thiomersal

Thiomersal atau yang sering disebut thimerosal adalah komponen turunan merkuri yang telah digunakan sebagai pengawet dalam vaksin dan produk perawatan kesehatan secara internasional salama beberapa tahun. Tidak ada kejadian serius selama penggunaan thiomersal dalam jangka waktu pemberian yang lama.

BIOLOGI SEL (YOL 6 NO 1 EDISI JAN-JUN 2017 ISSN 2252-858X/E-ISSN 2541-1225) PAGE 80 


\section{3) Stabilizer}

Stabilizer menghambat reaksi kimia dan mencegah komponen terpisah atau melekat pada vial selama proses pemindahan dan penyimpanan. Contoh dari stabilizer adalah gula seperti laktosa dan sukrosa, asam amino seperti glisin dan monosodiumglutamat (garam dari asam amino) protein seperti rekombinan albumin manusia (recombumin).

4) Buffer

Buffer digunakan untuk mencegah perubahan $\mathrm{pH}$, menyesuaikan tonisitas dan mepertahankan osmoralitas. Buffer yang paing umum digunakan adalah Natrium klorida (garam meja).

5) Surfactant

Surfactant adalah salah satu tipe emulsifier. Bahan ini membantu partikel tetap tersuspensi dalam cairan, mencegah menetap dan menggumpal, dengan cara menurunkan tegangan pada permukaan cairan. Salah satu contoh surfactant adalah poliorbat 80 (tween 80), yang terbuat dari sorbital (gula alkohol) dan asam oleat (asam lemak omega-9), yang juga digunakan dalam makanan seperti es krim. Surfactant juga digunakan dalam pembuatan shampo, pasta gigi, tinta dan pelembut kain.

6) Pelarut

Pelarut adalah substansi yang melarutkan zat lain, menciptakan larutan. Pelarut yang paling umum digunakan dalam kehidupan sehari-hari dan produksi vaksin adalah air.

7) Residual (zat sisa)

Residual adalah sejumlah kecil zat sisa dari bahan yang telah digunakan selama proses produksi vaksin. Jenis residual tergantung pada proses yang digunakan, yang mungkin terlibat dalam proses media kultur sel seperti protein telur, ragi, antibiotik seperti formalin.

8) Pengencer

Pengencer adalah cairan yang digunakan untuk mencairkan vaksin dalam konsentrasi tepat, segera sebelum proses pemberian. Bahan yang digunakan biasanya adalah air steril.

9) Turunan Hewan

Beberapa hewan memiliki kekhawatiran tentang produk turunan hewan seperti gelatin dalam vaksin. Hal ini mungkin karena alasan keagamaan atau kekhawatiran tentang keamanan asal produk hewan (IAC, 2014).

\section{KESIMPULAN}

1. Terdapat $36 \%$ dari informan menyatakan bahwa vaksinasi meningitis bagi calon jemaah haji/umroh merupakan langkah yang tepat dan patut didukung oleh semua pihak, karena dapat memberikan dampak yang sangat baik bagi kesehatan jemaah saat 
beribadah di tanah suci dan mencegah penularan penyakit tersebut kepada keluarga saat jemaah haji/umroh pulang ke tanah air. Sedangkan 64\% sisanya tidak memberikan tanggapan terhadap vaksinasi meningitis.

2. Permasalahan yang muncul dalam pelaksanaan vaksinasi/imunisasi meningitis adalah sebagai berikut: 1. Mengangggap vaksin adalah obat, 2. Menganggap vaksin dapat menghilangkan penyakit (di imunisasi akan tetapi tetap sakit), 3. Tidak terlihat manfaatnya secara langsung, 4. Terdapat bahan pengawet (mengandung racun), 5. Mengandung unsur babi/kera, mengandung lemak babi, sum-sum babi, 6. Tidak tercantum bahan pembuatan.

3. Kajian dari permasalahan: 1) vaksin bukanlah obat tetapi merupakan sediaan biologis yang diproduksi dari organisme hidup yang dapat merangsang imunitas, 2) vaksin diberikan untuk menghasilkan antibody yang berguna untuk melumpuhkan penyakit saat masuk kedalam tubuh, 3) perlindungan yang diberikan vaksin sekitar 80-90\% akan tetapi lebih baik daripada tidak samasekali, 4) bahan pengawet pada vaksin berguna untuk menghindari kontaminasi bakteri/fungi (ex. Thimerosal), 5) material turunan hewan dalam vaksin (serum, tripsin, asam amino, albumin, gelatin dll) di dapatkan dari sapi, babi dan kera, (6) Semua vaksin mengandung komponen aktif (antigen) yang berfungsi untuk membentuk respon imun.

\section{SARAN}

1. Disarankan kepada dinas sosial untuk lebih mengintensifkan sosialisasi mengenai keuntungan maupun kerugian dari imunisasi/vaksinasi meningitis dan lebih terbuka tentang bahan pembuatan vaksin pada masyarakat umum.

2. Untuk pihak yang terkait (pabrik/manufaktu) menciptakan inovasi baru untuk dapat memproduksi vaksin yang aman dan halal.

3. Diharapkan pemerintah dapat turut serta memantau dan menjamin keamanan serta kehalalan vaksin yang beredar di Indonesia.

\section{DAFTAR PUSTAKA}

Bahraen Raehanul. 2011. Pro Kontra Hukum Imunisasi dan Vaksinasi. https://muslim.or.id/7073-pro-kontra-hukum-imunisasi-dan-vaksinasi.html

Baratawidjaja, K. Tanpa Tahun. Penggunaan Herbal Medisin Untuk Imunostimulan dan Kemopreventif. FKUI Jakarta

Bruno G. 2005. Literature Education Series On Dietary Supplements. Colostrum. Huntigton College of Helth Sciences.

CDC. Tanpa tahun. Principles of vaccination. http://www.cdc.gov>downloads $>$ prinvac

Djauzi S, Rambe DS. 2013. Imunisasi: Sejarah dan Masa Depan. CDK-205/vol. 40 6, th. 2013 
Fitriani L, Marwayana ON. 2015. Potensi Propolis Sebagai Imunomodulator Pada Tikus (Rattus norvegicus Berkenhout, 1769) Galur Wistar yang diinuksi penilisin-G. Vol 3, No. 2, Desember 2015, hal 124-131.

Grabenstein J.D. 2013. What the world's religions teach, applied to vaccines and ammune globulin. Elsevier. Vaccine 31 (2013)2011-2023

Immunization Advisory Centre. 2014. Concern Vaccine Ingredients. University of Aucland.

Israr Y. 2008. Meningitis. Fakultas Pharmacy Universitas Riau. Riau

James G. Floyd. TT. Vaccinations for the Swine Herd. Alabamaa \& Mandauburn Universities. USA.

Mavituna AM. 2005. Production of recombinant human serum albumin in transgenic plants and plant cells. Dissertation

Pasal 1 ayat (1) Undang-Undang No. 17 Tahun 2013 tentang Organisasi Kemasyarakatan.

Peraturan Menteri Kesehatan Republik Indonesia. 2013. Tentang Pemberian Sertifikat Vaksinasi Internasional. KeMenKeS. Jakarta.

Probandari AN, Handayani S, Laksono NJ. 2013. Modul Field. Ketrampilan Imunisasi. Fak. Kedokteran Universitas 11 Maret. Surakarta.

Radji Maksum. 2009. Vaksin DNA: Vaksin Generasi ke Empat. Majalah Ilmu Kefarmasian, Vol. VI, No. 1, April 2009, 28 - 37

Rahmatiah. 2015. Pengaruh Vaksinasi Terhadap Kekebalan Tubuh Bayi. E-Buletin LPMP Sulsel. ISSN 2355-3189. 06 April 2015.

Schenerman MA et al. 2003. Characteriation of Alternatives Animal Derived Raw Material. Journal Bio Process International

Souvriyanti E, Rezeky S, dan Hadinegoro. 2004. Hubungan vaksin Measles, Mumps, Rubella (MMR) dengan Kejadian Autisme. Jurnal Sari Pediatri, Vol. 6, No. 1.

Sulistiyowati E. 2010. Obat Dan Pengaruhnya Terhadap Tubuh Manusia. FMIPA. Universitas Negeri Yogyakarta.

Tuasikal A. 2011. Hukum Vaksinasi dari Enzim Babi. rumaysho.com /2025-hukumvaksinasi-dari-enzim-babi.html

Yuwono D. 1995. Perkembangan Baru Dalam Tekhnologi Vaksin Virus. Media LitbangKes. Vol 5 no 2. 